https:/ / doi.org/10.18485/iipe_cpti.2020.ch6

\title{
HIPERSONIČNO ORUŽJE: POREMEĆAJ STRATEŠKOG BALANSA ILI NOVA TRKA U NAORUŽANJU?
}

\author{
Bogdan STOJANOVIĆ
}

Apstrakt: Testiranje i uvođenje hipersoničnog oružja u operativnu upotrebu obesmislilo je megalomanske projekte ulaganja u raketnu odbranu. Pokušaj izbegavanja uzajamnog osiguranog uništenja, kroz razvijanje efikasnog raketnog štita od strane $\mathrm{SAD}$, oslikavao je nameru poremećaja strateškog balansa onemogućavanjem eventualne odmazde i sprečavanjem drugog udara protivnika. Hladnoratovski koncepti uzajamnog osiguranog uništenja $(M A D)$ i strategije odvraćanja bili bi dovedeni u pitanje. Hipersonično oružje - iako poslednja reč nauke i tehnologije - ne predstavlja revoluciju u vojnim poslovima. Ono nije sposobno da poremeti strateški vojni balans između nekadašnjih hladnoratovskih protivnika, ali predstavlja vid garancije njegovog očuvanja. Uvođenjem hipersoničnog oružja u operativnu upotrebu, Rusija nije poremetila strateški balans u svoju korist već je onemogućila SAD da to uradi razvijanjem sistema protivraketne odbrane. Počela je nova trka u naoružanju koje se kreće pet i više puta brže od brzine zvuka. Obrisi nove trke nalik su osvajanju svemira, bez ugrožavanja strateške ravnoteže, ali je ta trka izuzetno značajna u kontekstu prestiža. Članstvo u "hipersoničnom klubu” biće privilegija najmoćnijih država, poput nekadašnjeg ekskluziviteta koji je nudilo članstvo u klubu nuklearnih sila.

Ključne reči: hipersonično oružje, strateški balans, strategija odvraćanja, uzajamno osigurano uništenje, protivraketni štit, revolucija u vojnim poslovima, SAD, Rusija, Kina.

${ }^{1}$ Autor je istraživač saradnik u Institutu za međunarodnu politiku i privredu, Beograd, e-mail: bogdan.stojanovic@diplomacy.bg.ac.rs

Rad je nastao u okviru naučnoistraživačkog projekta „Srbija i izazovi u međunarodnim odnosima 2020. godine”, koji finansira Ministarstvo prosvete, nauke i tehnološkog razvoja RepublikeSrbije, a realizuje Institut za međunarodnu politiku i privredu tokom 2020. godine. 


\section{Uvodne napomene}

Govor ruskog predsednika Vladimira Putina (Владимир Путин), od 1. marta 2018, u kome je objavio nove tipove ruskog naoružanja, označio je ulazak $u$ novu eru tehnologije ratovanja. ${ }^{2}$ Osim što je šokirao javnost tehnološkim iskorakom koji je Rusija nesumnjivo napravila, Putin je uveo svet u novu trku u naoružanju. Uz novu vazduh-zemlja balističku raketu „Kinžal”, novu interkontinentalnu balističku raketu ",Sarmat", prve krstareće rakete na nuklearni pogon neograničenog dometa kodnog imena "Burevestnik", podvodnog drona na nuklearni pogon „Posejdon” i mornaričke hipersonične rakete "Cirkon", posebnu pažnju privukao je novi tip hipersoničnog oružja kodnog imena "Avangard", koje leti 20 puta brže od brzine zvuka "cik-cak” trajektorijom što ga čini neuhvatljivim za protivraketnu odbranu. ${ }^{3}$ Upečatljiva je rečenica u navedenom govoru: „Niste nas slušali, ali od sada ćete morati”, upućena je nekadašnjem hladnoratovskom protivniku - Sjedinjenim Američkim Državama (dalje: SAD). ${ }^{4}$

Više od dvadeset meseci nakon govora ruskog predsednika Rusija je postala prva država koja je zvanično u svoj operativni vojni arsenal uvela hipersonično naoružanje, tačnije sistem „Avangard" ${ }^{5}$ Time je kreirala nove tehnološke izazove u globalnoj trci u naoružanju koje će nesumnjivo pratiti SAD i Kina, a potencijalno i neke druge države. Posledice do kojih će dovesti uvođenje novog tipa oružja nisu revolucionarnog karaktera u smislu da menjaju prirodu rata, ali će doći do znatnog povećanja efikasnosti neutralisanja meta u prvom udaru, lakšeg prodiranja kroz neprijateljske odbrane i decentralizacije operativne komande koja mora da reaguje $u$ daleko kraćem roku. Ukoliko bi hipersonično oružje bilo korišćeno protiv država sa ograničenim strateškim kapacitetima za drugi udar (eng. second strike capability), ono bi moglo da spreči odmazdu protivnika, što bi konstantno provociralo preventivni udar na obe strane. Prvo, strana koja poseduje hipersonično oružje snažnim prvim udarom mogla bi da

2 "Putin unveils new nuclear weapons", 1.3.2018, CBC News: The National, Youtube video, https:/ / www.youtube.com/watch?v=X7bUHc4jAI0, 2/2/2020.

${ }^{3}$ Ibid.

${ }^{4}$ Ibid.

5 "Avangard: Russia deploys hypersonic nuclear-capable missiles", Al Jazeera, 27 December 2019, https: //www.aljazeera.com/news/2019/12/avangard-russiacommissions-intercontinental-hypersonic-weapon-191227142922561.html, 13/3/2020. 
neutrališe protivnikov skromni kapacitet da odgovori. Drugo, država koja nema garanciju efikasnog odgovora kroz drugi udar razmišljala bi da prva otpočne napad.

$\mathrm{Na}$ prvi pogled deluje da hipersonično oružje unosi nestabilnost $\mathrm{u}$ odnose između država i da predstavlja generator kriza, što ipak nije slučaj. Naime, ovo oružje je rezervisano za vojno najsposobnije države koje već poseduju dovoljne kapacitete za drugi udar i kojima $\mathrm{u}$ tom smislu hipersonično oružje ne predstavlja značajnu prednost. Hipersonično oružje zapravo osigurava stabilnost između vojno najmoćnijih država sveta kroz garanciju „uzajamnog osiguranog uništenja” (eng. mutual assured destruction). ${ }^{6}$ Može se zaključiti da ono unosi stratešku ravnotežu koja bi mogla biti poremećena efikasnim protivraketnim štitom, sposobnim da neutrališe napade drugim strateškim naoružanjem koje nije hipersonično. Američki predsednik Džordž Buš (George Walker Bush), 2002. godine naveo je da je Sporazum o antibalističkim raketama (eng. Anti-Ballistic Missile Treaty) iz 1972. sada „iza nas" i da je neophodno razviti protivraketni štit „što je pre moguće” kako bi se zaštitili od "rastućih raketnih pretnji”. ${ }^{7}$ Rusija kao odgovor na američki protivraketni štit razvija hipersonično oružje koje bez problema može da probije svaku odbranu, pa i pomenuti „štit”, čime je osigurala „drugi udar" u eventualnom vojnom sukobu. Hipersonično oružje osigurava stratešku ravnotežu, ali verovatno označava i jednu novu trku u naoružanju. Za razliku od hladnoratovske trke, u kojoj su postojale dve supersile, nova trka osim Rusije i SAD sasvim sigurno uključuje i Kinu, a možda i neke druge vojno sposobne države poput Francuske, Indije ili Ujedinjenog Kraljevstva.

\section{Hipersonično oružje i budućnost ratovanja}

Govoreći vojnim rečnikom, sva oružja od pištolja, preko artiljerije do interkontinentalnih balističkih raketa, spadaju u grupu balističkog

\footnotetext{
${ }^{6}$ Драган Петровић и Богдан Стојановић, Равнотежа нуклеарне моћи САД и Русије (СССР), Пешић и синови, Центар за развој међународне сарадње, Београд, 2012, стр. 140-141.

${ }^{7}$ Wade Boese, "U.S. Withdrawal From ABM Treaty; Global Response Muted", Arms Control Today, July/ August 2002, https:/ / www.armscontrol.org/act/2002-07/news/ us-withdraws-abm-treaty-global-response-muted, 15/3/2020.
} 
naoružanja. Trajektorija ispaljenog projektila bez obzira da li je reč o metku ili raketi, usmerena je nišanskim spravama i zakonima fizike. Putanja kretanja projektila unapred je determinisana bez mogućnosti da se autonomno na nju utiče. Zajednička osobina celokupnog balističkog oružja je nepreciznost, što je moralo biti nadomešteno velikom destruktivnom moći i masovnim ispaljivanjem. Prosečan vojnik koji nosi pušku nije bio u stanju da pogodi metu koja se kreće, posebno kada je i on sam bio pod oružanom vatrom. Niska verovatnoća da ćete pogoditi metu balističkim oružjem povećavana je brojem ispaljenih metaka. Tako je matematika rata zahtevala velike vojske, ogromnu industrijsku proizvodnju i mnogo utrošenog vremena. ${ }^{8}$ Posle Drugog svetskog rata $u$ vojne arsenale uvodi se precizno navođeno oružje koje menja prirodu ratovanja. Preciznost je omogućila efikasnost vojski uz korišćenje manjeg broja ljudi na frontu, ali je istovremeno rasla i verovatnoća da će vojnik nastradati $u$ ratu. Stoga se razvijaju i sistemi zaštite od preciznijeg oružja. Tenk je postao oklopljen snažnijim materijalima, bombarderi su razvijali stelt tehnologiju, a brodovi i nosači aviona postaju "glineni golubovi" ukoliko nemaju antiraketne sisteme. Istovremeni napredak ofanzivnih i defanzivnih sistema dovodi do „začaranog kruga" nadmetanja. Napadač je razmišljao o tome kako da porazi protivnikovu odbranu, dok je onaj koji se brani razmišljao kako da neutrališe ofanzivne kapacitete protivnika. Razvoj novog tipa ofanzivnog naoružanja koje nazivamo ",hipersoničnim", uvelo je stratege, inženjere i tehnološke inovatore $u$ problem kako da odgovore na izazov i razviju efikasnu odbranu od takvog oružja.

Termin „hipersonično" označava kretanje nekog objekta pet i više puta od brzine zvuka koja se označava Mahovim brojem 1. ${ }^{9}$ Još šezdesetih godina $X X$ veka avioni sa posadom leteli su hipersoničnim brzinama. Američki avion „X-15” još pre 53 godine napravio je rekord u brzini letelice sa pilotom

\footnotetext{
${ }^{8}$ George Friedman, "Where Hypersonic Weapons Fit in the Future of War", Geopolitical Futures, January 10, 2018, https:/ / geopoliticalfutures.com/hypersonic-weapons-fitfuture-war/, 12/3/2020.

${ }^{9}$ Mahov broj označava odnos brzine kretanja objekta i brzine zvuka. Ime je dobio po austrijskom fizičaru Ernstu Mahu iz kasnog XIX veka. Označava se slovom „"M“ i zavisi od gustine vazduha. Pri normalnim uslovima brzina zvuka (Mahov broj 1) iznosi 330m/s ili 1223 km/h. Videti: „Mach number“ , National Aeronautics and Space Administration, Glenn Research Center, https://www.grc.nasa.gov/www/k12/airplane/mach.html, 12/1/2020.
} 
koji je do danas na snazi i iznosi neverovatnih 6,7 Maha. ${ }^{10}$ Međutim, kvalitativna razlika novog hipersoničnog oružja u odnosu na prethodnike nije isključivo u brzini kretanja jer su hipersonične brzine postizale mnoga druga oružja decenijama unazad. Neverovatna ofanzivna sposobnost hipersoničnog oružja leži u manevarbilnosti i neobičnim visinama na kojima se kreće, što ih čini potpuno nepredvidivim za protivničku odbranu.

Postoje dva osnovna tipa novog hipersoničnog oružja. Prvo, hipersonični "klizeći” objekti (eng. hypersonic glide vehicles - HGV) koji se lansiraju sa raketa, tj. odvajaju od njih $\mathrm{u}$ jednom momentu leta, $\mathrm{i}$ hipersonične krstareće rakete (hypersonic cruise missiles - HCM) koje pokreće autonomni motor, poput naprednih mlaznih ili najsofisticiranijeg "skramdžet" (eng. scramjet) motora. ${ }^{11}$ Potrebno je da se napomene da i hipersonična, poput klasične raketne tehnologije, može biti upotrebljena $u$ vojne ili civilne svrhe. Dualna upotreba tehnologije (eng. dual use technology), osim kao oružje u ratnim akcijama, znači i nevojnu upotrebu u svemirskim lansiranjima, istraživačkim misijama i transportu robe i ljudi.

Oba tipa hipersoničnog oružja predstavljaju značajno ubojitija sredstva u odnosu na sve dosadašnje tipove krstarećih i balističkih raketa. Bez obzira na tu činjenicu, hipersonično naoružanje ne čini ništa ranjivijim države koje nemaju efikasni protivraketni štit za dosadašnje tipove oružja. Potencijalno, isključivo države posednice efikasnog protivraketnog štita imaju razloga za brigu zbog hipersoničnog oružja, jer ono onemogućava odbranu od raketnog napada. U prevodu, širenje hipersoničnog oružja u geopolitičkom i geostrateškom smislu ne ide na ruku SAD koje su milijarde dolara uložile u svoj sistem protivraketne odbrane, koji predviđa radarske i lansirne stanice daleko izvan američke teritorije. ${ }^{12} \mathrm{U}$ izveštaju RAND korporacije o širenju hipersoničnih raketa, navodi se uloga novog oružja kao "game changer" u budućim strateškim razmatranjima zbog sposobnosti da probije

${ }^{10} \mathrm{~J}$. R. Wilson, "The emerging world of hypersonic weapons technology", Special report, Military \& Aerospace Electronics, 2019, p. 16.

${ }^{11}$ Richard H. Speier, George Nacouzi, Carrie A. Lee and Richard M. Moore, "Hypersonic Missile Nonproliferation: Hindering the Spread of a New Class of Weapons", Report, RAND Corporation, 2017, pp. 2-5.

${ }^{12}$ Više o američkom projektu antiraketne odbrane u: Andrew Futter, Ballistic Missile Defence and US National Security Policy: Normalization and acceptance after the Cold War, Routledge, New York, 2013. 
sve aktuelne odbrambene sisteme. ${ }^{13}$ Iako još uvek nedovršen, američki raketni štit je obesmišljen novim tipom ofanzivnog oružja.

HGV su vrhunac tehnologije jer se "otpuštaju” sa balističke rakete na visinama preko $50 \mathrm{~km}$, ali mogu prelaziti i visinu od $100 \mathrm{~km}$, koje potom „klize” ka meti prelazeći gornje slojeve atmosfere. ${ }^{14} \mathrm{HGV}$ lete na nižim visinama od balističkih raketa, a nepredvidivost trajektorije letenja koja može da varira tokom cele putanje do mete, čini je neuhvatljivom za protivraketnu odbranu. ${ }^{15} \mathrm{HGV}$ nemaju samostalni motor, ali su dizajnirane tako da proizvode jednak potisak i održavaju neverovatne brzine i bez motora. ${ }^{16}$ Trajektorije kretanja HGV su značajno nepredvidljivije u odnosu na nekadašnju tehnologiju MaRV (eng. maneuvering reentry vehicles) koje menjaju trajektoriju samo u terminalnoj fazi leta. MaRV lete na velikim visinama u balističkom modu tokom najvećeg dela leta, što ih čini ranjivim za antiraketne sisteme koji operišu na egzoatmosferskim visinama i obaraju rakete dok su na srednjem kursu. ${ }^{17} \mathrm{Na}$ drugoj strani, HGV zanemarljivi deo leta $u$ početnoj fazi provode $u$ balističkom modu, dok se nakon toga "otpuštaju" i na malim visinama lete ka meti potpuno nepredvidivom trajektorijom, što ih čini neranjivim za sve postojeće protivraketne sisteme. ${ }^{18}$ Suštinska razlika u odnosu na balističke rakete nije brzina, jer i balističke rakete lete hipersoničnim brzinama, već u tome što HGV lete na malim visinama i što gotovo tokom čitavog leta menjaju trajektoriju.

HGV dodatno kompresuju vreme za reagovanje protivničkih odbrambenih sistema. Države koje nemaju pristup satelitskim radarima za detekciju lansiranja balističkih raketa i oslanjaju se na zemaljske radare, $\mathrm{u}$ najboljem slučaju mogu detektovati HGV šest minuta pre udara, što je prekasno za bilo kakav pokušaj obaranja. ${ }^{19}$

\footnotetext{
${ }^{13}$ Richard H. Speier, George Nacouzi, Carrie A. Lee and Richard M. Moore, "Hypersonic Missile Nonproliferation: Hindering the Spread of a New Class of Weapons" op. cit., p. 1.

${ }^{14}$ Ibid., p. 2.

${ }^{15}$ Ibid., p. 3.

${ }^{16}$ Ibid., p. 7.

${ }^{17}$ Ibid., p. 8-9.

18 Ibid.

${ }^{19}$ Ibid., p. 11.
} 
Druga vrsta hipersoničnog oružja jesu HCM koje mogu biti lansirane sa zemlje, brodova ili iz vazduha. U početnoj fazi leta do dostizanja brzine 45 Maha pokreće ih najčešće klasični raketni pogon kada let „preuzima” autonomni motor, najčešće „skramdžet”, koji dalje ubrzava raketu i daje joj neverovatnu mogućnost manevrisanja na visinama između 20 i $30 \mathrm{~km} .{ }^{20}$

Destruktivna moć hipersoničnog oružja zavisi od toga da li nosi konvencionalne ili nuklearne bojeve glave. Osim toga, zbog velikih brzina, one mogu napraviti ogromnu štetu i čistom kinetičkom energijom bez eksplozivnog punjenja. Na primer, hipersonično oružje teško 500 kg koje leti brzinom oko 8 Maha, bez eksplozivnog punjenja, čistim kinetičkim udarcem pravi eksplozivni udar ekvivalentan udaru tri metričke tone TNTa (trinitrotoluena). ${ }^{21}$ To je izuzetno velika snaga jer je, poređenja radi, nuklearna bomba bačena na japanski grad Hirošimu, avgusta 1945. godine, težila nekih $42 \mathrm{~kg}$ i ostvarila prinos od $12,5 \mathrm{Kt}^{22}$

Države koje ne poseduju efikasne antiraketne sisteme protiv balističkih raketa neće osetiti značajnu stratešku promenu uvođenjem hipersoničnog oružja, jer bez takvog štita one su podjednako ranjive na obe vrste naoružanja (klasično raketno i hipersonično). Iz tog razloga, hipersonično oružje jeste značajan napredak u tehnologiji uvećavajući ofanzivne kapacitete, ali samo u kontekstu probijanja protivničkih protivraketnih odbrana. Za sve države koje ne poseduju takve protivraketne sisteme, hipersonično oružje ne predstavlja nikakvu kvalitativnu razliku u odnosu na postojeće sisteme balističkih raketa.

\section{Evolucija, a ne revolucija u vojnim poslovima}

Sintagmu "revolucija u vojnim poslovima” (dalje: RVP) smislili su Sovjeti šezdesetih godina XX veka da bi objasnili masovno uvođenje nuklearnog naoružanja $\mathrm{u}$ vojne arsenale. ${ }^{23}$ Koncept je prešao granice

\footnotetext{
${ }^{20}$ Ibid., p. 12.

${ }^{21}$ Ibid., p. 13.

${ }^{22}$ Eric A. Croddy and James J. Wirtz (eds.), Weapons of mass destruction: an encyclopedia od worldwide policy, technology and history, ABC Clio, Santa Barbara, California, 2005, p. 135.

${ }^{23}$ Bartelemi Kurmon i Darko Ribnikar, Asimetrični ratovi, NIC Vojska, Beograd, 2003, str. 107.
} 
Sovjetskog Saveza i postao prihvaćen na Zapadu, označivši pobedu kvaliteta naoružanja nad kvantitetom. Značaj ovog koncepta leži u linearnom shvatanju istorijskog razvoja tehnologije naoružanja, prema kome su informacione tehnologije važne za promenu prirode ratovanja, koliko i zamena konjske snage mehaničkom. ${ }^{24}$ Neki autori poput Endrjua Krepinjeviča (Andrew Krepinevich) navode deset takvih "revolucija”, posmatrajući period od 1300. godine do danas. ${ }^{25}$ Poznata je izjava Alberta Ajnštajna (Albert Einstein), jednog od najvećih fizičara, kako „nije poznato kakvo će se oružje koristiti u Trećem svetskom ratu, ali je siguran da će se u Četvrtom koristiti štapovi i kamenje".${ }^{26}$ Ova izjava nije daleko od istine jer iako savremeni rat nije promenio svoju prirodu, u smislu neophodnog uključivanja oružane borbe sukobljenih vojski, on je promenio sredstva kojim se rat vodi. Metode ratovanja su vremenom postajale destruktivnije i sposobnije da nanesu masovne ljudske žrtve drugoj strani. Može se reći da revolucija u vojnim poslovima zapravo predstavlja revoluciju $\mathrm{u}$ tehnologiji ratovanja, jer u savremenom ratu "nebo ima oči, meci imaju mozak, a pobeda pripada državi čija vojska ima bolju mrežu podataka" ${ }^{27}$ Budućnost ratovanja je takva da uključuje najrazličitija sredstva poput kompjuterskih virusa, elektromagnetne impulse, lasere, veštačku inteligenciju i sl., ali „eksplozivni“ deo ratovanja ostaće nepromenjen jer će uvek uključivati razaranja i ubijanja. U tom smislu, govoriti o tzv. "humanitarnim” intervencijama je licemerno, o čemu najbolje svedoče napadi na SR Jugoslaviju 1999. godine, kao i kasniji ratovi u Avganistanu 2001. i Iraku 2003. godine. Francuski postmodernista Žan Bodrijar (Jean Baudrillard), opisujući Zalivski rat rekao je da je to „rat koji se nije desio" ${ }^{28}$ Brojne ljudske žrtve, od kojih je veliki procenat civila, svedoče da se rat ",ipak dešava”, jednako danas koliko i u srednjem veku, samo što je ubijanje i razaranje još efikasnije nego nekad.

${ }^{24}$ Meri Kaldor, Novi i stari ratovi - organizovano nasilje u globalizovanoj eri, Beogradski krug, Beograd, str. 15.

${ }^{25}$ Bartelemi Kurmon i Darko Ribnikar, Asimetrični ratovi, op. cit., str. 108.

${ }^{26}$ Citirano u: Čarls Kegli i Judžin Vitkof, Svetska politika, Centar za studije Jugoistočne Evrope, FPN i DA Ministarstva spoljnih poslova SCG, Beograd, 2006, str. 666.

${ }^{27}$ Ibid., str. 675.

${ }^{28}$ Videti: Jean Baudrillard, The Gulf War did not take place, Bloomington: Indiana University Press, 1995. 
Sredstva poput hipersoničnog oružja uvećavaju preciznost i destruktivnu moć vojski. Hipersonični let oružja nije značajna novina u ratovanju. Kao što smo objasnili - promena koju donosi hipersonično naoružanje pretežno se tiče preciznosti, kontrole leta i neverovatne manevarbilnosti koja projektil čini neuhvatljivim za protivničke odbrane. Jačanje ofanzivnih kapaciteta posednika hipersoničnog oružja stoga ne donosi radikalnu promenu u načinu ratovanja, već samo garantuje prodornost kroz neprijateljsku odbranu (protivraketni štit). Kada govorimo o hipersoničnom naoružanju, iskorak koji je napravljen nije takav da bi bio uporediv prelasku sa konjske na mehaničku snagu ili sa uvođenjem barutnog oružja.

Zaključujemo da je hipersonično oružje dovelo do evolucije, a ne revolucije $\mathrm{u}$ vojnim poslovima. ${ }^{29}$ Napredak $\mathrm{u}$ garantovanju efikasnosti pogotka neprijateljskih meta značajan je evolutivni iskorak, ali u tehnološkom i operativnom kontekstu nedovoljan da bi izvršio revoluciju u ratovanju. Posednik hipersoničnog oružja, ukoliko nema efikasan protivraketni štit, nije u značajnoj ofanzivnoj prednosti u odnosu na rivale.

\section{Uloga hipersoničnog oružja u strategiji odvraćanja}

Strategija i praksa racionalnog odvraćanja vuče korene iz Hladnog rata i „zlatnog doba” strateških studija kada su dve supersile (SAD i Sovjetski Savez) gomilale nuklearno oružje i trijade njegove isporuke, a sve u cilju obezbeđivanja uzajamnog osiguranog uništenja (eng. mutual assured destruction). ${ }^{30} \mathrm{U}$ jezgru odvraćanja neprijatelja od napada leži strah da će i on sam biti predmet uništenja. Da bi se taj efekat osigurao, potrebna je sposobnost drugog udara, tj. da čak i ukoliko ste prvi napadnuti posedujete dovoljno kapaciteta da uzvratite istom merom. Da bi se osigurala sposobnost drugog udara, neophodno je da posedujete interkontinentalne balističke rakete koje se lansiraju iz silosa ili sa podmornica, kao i strateške

${ }^{29}$ Alan Cummings, "Hypersonic weapons: tactical uses and strategic goals", War on the rocks, November 12, 2019, https://warontherocks.com/2019/11/hypersonicweapons-tactical-uses-and-strategic-goals/, 10/1/2020.

${ }^{30} \mathrm{O}$ dometima i ograničenjima nuklearnog odvraćanja više u: Богдан Стојановић, „Преиспитивање теорије и праксе нуклеарног одвраћања“ , Нациионални интерес, Година X, Vol. 17, Број 2, 2013, стр. 141-172. 
bombardere od kojih je jedan broj konstantno u vazduhu čekajući naredbu za napad.

Kada govorimo o hipersoničnom oružju u kontekstu strategije odvraćanja, njegova uloga nije revolucionarna, ali istovremeno ni zanemarljiva. Hipersonično oružje još više kompresuje vreme preostalo protivniku da pokrene sopstveni napad. U prevodu, ukoliko država koja raspolaže hipersoničnim oružjem isto lansira prema neprijatelju, on će za to znati tek šest minuta pre udara ukoliko ne raspolaže satelitskim radarima, što je duplo kraći vremenski period u odnosu na balističke rakete. ${ }^{31}$ To znači da bi, čak i u slučaju sposobnosti za drugi udar, ta država bila onemogućena da ga sprovede zbog manjka vremena za izdavanje naredbe i njeno izvršenje. Stoga postojanje hipersoničnog oružja može uzrokovati veću decentralizaciju vojne komande i spustiti nivo odlučivanja na niže operativne nivoe. Razlog tome je hipotetički scenario napada hipersoničnim oružjem na političko i vojno rukovodstvo države (tzv. dekapitacija), koje ne bi stiglo da reaguje i izda naredbu o kontraudaru. Međutim, kada se govori o kataklizmičnim scenarijima i nemogućnostima neke zemlje da vremenski odgovori na napad, potrebno je istaći da bi takav napad uključivao nuklearno punjenje hipersoničnog oružja. Naime, konvencionalni udar, koliko god precizan i efikasan bio, ne može potpuno neutralisati protivnika u prvom udaru, tako da je takav napad nemoguće sprovesti bez nuklearnih kapaciteta. Isto tako, sposobnost protivnika da odvrati napad moguća je isključivo uz nuklearne kapacitete jer jedino oni garantuju nanošenje "neprihvatljive štete" protivniku. ${ }^{32}$ Dakle, strategija i praksa odvraćanja nesprovodiva je bez adekvatnih nuklearnih kapaciteta.

Uticaj hipersoničnog oružja na strategiju odvraćanja, osim kompresije vremena, može biti i kroz uvećavanje mogućnosti preventivnog udara. Upravo ta nemogućnost protivnika da adekvatno pokrene kapacitete za drugi udar (ukoliko ne raspolaže satelitskim radarskim sistemima), dovodi

${ }^{31}$ Prilikom napada balističkom raketom zemaljski radar će detektovati napad 12 minuta pre udara. Videti: Richard H. Speier, George Nacouzi, Carrie A. Lee and Richard M. Moore, "Hypersonic Missile Nonproliferation: Hindering the Spread of a New Class of Weapons", op. cit., p. 11.

${ }^{32}$ Američki hladnoratovski ministar odbrane Robert Maknamara definisao je "neprihvatljivu štetu“ kao uništenje $1 / 5$ do $1 / 4$ neprijateljske populacije i polovine do 2/3 neprijateljskih industrijskih kapaciteta. Videti: Драган Петровић и Богдан Стојановић, Равнотежа нуклеарне моћи САД и Русије (СССР), op. cit., str. 129. 
do veće verovatnoće preventivnog udara na tu državu. Sledstveno tome, država koja ne raspolaže sistemima za rano upozorenje može uvesti doktrinu "lansiraj na upozorenje” (eng. launch on warning), što bi u praksi označavalo da prva signalizacija leta hipersonične rakete ka njenoj teritoriji daje odrešene ruke svim jedinicama da uzvrate, a da ne čekaju naređenje iz vrhovne komande.

Vremenska sekvenca od uočavanja pretnje do lansiranja protivudara poznata je kao „OODA petlja” (eng. Observe, Orient, Decide, Act Loop), koju je koncipirao američki vojni strateg Džon Bojd (John Boyd). ${ }^{33}$ "OODA" uključuje sled događaja od uočavanja pretnje, preko orijentisanja i odluke šta činiti do krajnje akcije delovanja. U pomenutih šest minuta - od momenta saznanja da je na vas izvršen napad hipersoničnim oružjem jednostavno je nemoguće sprovesti sve neophodne aktivnosti do krajnje akcije, osim ukoliko ne preskočite neki korak. Prema tome, hipersonično oružje na neki način dodatno destabiliše ionako problematičan koncept nuklearnog odvraćanja. ${ }^{34}$

\section{Poremećaj ili jačanje strateškog balansa?}

Tokom Hladnog rata postojala je ravnoteža u kontekstu vojne moći i ona nije mogla biti narušena iracionalnim gomilanjem nuklearnih bombi sa obe strane, jer "višak moći" u situaciji uzajamnog osiguranog uništenja ne znači mnogo. Hladni rat je završen političkom i ekonomskom pobedom SAD, ali je na vojnom polju Rusija kao naslednica nekadašnjeg Sovjetskog Saveza održala nuklearni paritet i vojnu ravnotežu. Međutim, američkim napuštanjem „ABM" sporazuma i razvojem protivraketnog štita, koji bi u teoriji mogao da neutrališe rusko strateško naoružanje, došlo je do poremećaja te ravnoteže. Iako SAD nisu uspele da stvore stoprocentno efikasan protivraketni štit, one su aktivno radile u tom cilju, okružujući

${ }^{33}$ Više o ovom konceptu u: Daniel Ford, A Vision So Noble - John Boyd, the OODA Loop, and Americas War on Terror, CreateSpace Independent Publishing Platform, 2010.

${ }^{34}$ Problem pretpostavke racionalnosti aktera otežava stoprocentnu funkcionalnost strategije odvraćanja. Bogdan Stojanović govori o stalno „konstruisanoj racionalnosti“ koja nikada nije objektivnog karaktera i koja može dovesti do pogrešnih kalkulacija. Više u: Богдан Стојановић, „Преиспитивање теорије и праксе нуклеарног одвраћања“" Нациионални интерес, Година X, Vol. 17, Број 2, 2013, стр. 141-172. 
teritoriju Rusije sa radarima i lansirnim stanicama, navodeći Iran kao glavnu pretnju i razlog gomilanja naoružanja $60 \mathrm{~km}$ od ruske granice. ${ }^{35}$

U intervjuu za TASS, ruski predsednik Vladimir Putin rekao je: „Razvijajući svoj antibalistički sistem, Amerikanci su želeli da poremete stratešku stabilnost i ravnotežu, misleći da ako kreiraju raketni kišobran, druga strana neće moći adekvatno da odgovori u slučaju njihove upotrebe nuklearnog oružja." ${ }^{36}$ Nadovezujući se na ovaj argument, Putin je objasnio razlog ruskog razvijanja hipersoničnog naoružanja: „Ipak, nakon što smo razvili moderne hipersonične sisteme, uključujući i one koje lako izbegavaju bilo koji protivraketni sistem, održali smo stratešku stabilnost i ravnotežu. To je suštinski važno ne samo za nas, već za globalnu bezbednost." ${ }^{37}$

Hipersonično oružje posledično utiče na strateški balans između nekadašnjih hladnoratovskih rivala, uz dodatak Kine kao nove varijable $u$ vojnoj kalkulaciji. Međutim, ono utiče pozitivno na uspostavljanje ravnoteže koja je mogla biti poremećena efikasnim antiraketnim sistemom koje su razvijale SAD. Zaključujemo da rusko hipersonično oružje jača stratešku ravnotežu, ali na drugoj strani uvodi svet u novu ",trku” u naoružanju, koja će za razliku od Hladnog rata imati najmanje tri učesnika.

\section{Nova trka za ulazak $u$ "hipersonični klub"}

Rusija je država koja je najviše odmakla u razvoju novog hipersoničnog naoružanja. Posle čuvenog govora iz marta 2018. godine, kada je javnosti obelodanjeno postojanje hipersoničnog oružja u ruskom arsenalu, već krajem decembra 2019. godine Rusija je uvela sistem "Avangard” u operativnu upotrebu. ${ }^{38}$ Rusija je, za sada, jedina država sveta koja je to učinila. Dva dana pre uvođenja "Avangard" sistema u operativnu upotrebu, Putin je u pomalo ironičnom tonu rekao da će druge države "pokušati da nas sustignu", aludirajući na razvoj hipersoničnog

\footnotetext{
${ }^{35}$ Videti: Andrew Futter, Ballistic Missile Defence and US National Security Policy: Normalization and acceptance after the Cold War, Routledge, New York, 2013.

36 "Russia's new hypersonic weapons help maintain global strategic balance - Putin", Putin's interview, Tass, 2 March 2020, https:/ /tass.com/politics/1125437, 15/3/2020. ${ }^{37}$ Ibid.

38 "Avangard: Russia deploys hypersonic nuclear-capable missiles", Al Jazeera, 27 December 2019, op. cit.
} 
naoružanja. ${ }^{39}$ Početkom 2020. godine ruski predsednik Vladimir Putin izjavio je da „ne postoji nijedna država na svetu osim Rusije koja poseduje hipersonično naoružanje" ${ }^{40}$

Gotovo svakodnevno ruski i zapadni mediji objavljuju podatke o napretku Rusije u domenu hipersoničnog oružja. U februaru 2020. godine, rusko ministarstvo odbrane objavilo je da je Rusija razvila novu vazduhzemlja hipersoničnu raketu, neuhvatljivu za protivničke odbrane, a koja će biti montirana na ruske avione ",Su-57" ${ }^{41}$ Nova raketa je po performansama slična balističkoj raketi „Kinžal”, koja je već u operativnoj upotrebi i koja se lansira iz vazduha, ali ima poboljšane manevarske sposobnosti. ${ }^{42}$

Krstareća raketa na nuklearni pogon, koja leti hipersoničnim brzinama kodnog imena „Burevestnik” ima neograničeni domet, takođe je prezentovana u Putinovom govoru od 1. marta 2018. godine. ${ }^{43}$ To je prva raketa $\mathrm{u}$ istoriji ratovanja na nuklearni pogon sposobna da manevriše na osnovu konfiguracije terena i određuje nove trajektorije kako bi izbegla protivraketne sisteme. ${ }^{44}$ Prema pojedinim podacima, sposobna je da leti i na samo 10 metara visine od tla, pa je protivnički odbrambeni sistemi ne mogu ni detektovati, a kamoli oboriti. Teorijski, ona je sposobna da krstari mesecima po svetu pre nego što udari tamo gde je programirana.

U februaru 2020. godine Rusija je sprovela i prvi lansirni test pomorske hipersonične rakete „Cirkon", na kojoj se radi još od 2011. godine. ${ }^{45}$ Cirkon

${ }^{39}$ Nathan Hodge, "Putin claims Russia is world leader on hypersonic weapons", CNN, December 25, 2019.

${ }^{40}$ Darya Tarasova, Zahra Ullah and Jack Guy, "Russia's Vladimir Putin oversees hypersonic missile test near Crimea", CNN, January 9, 2020.

${ }^{41}$ Franz-Stefan Gady, "Report: Russia Has Developed Prototype of Air-to-Ground Hypersonic Missile for Su-57", The Diplomat, 25 February 2020, https://the diplomat.com/2020/02/report-russia-has-developed-prototype-of-air-to-groundhypersonic-missile-for-su-57/, 20/3/2020.

42 Ibid.

43 "Putin unveils new nuclear weapons", op. cit.

${ }^{44}$ Franz-Stefan Gady, "Russia Reveals 'Unstoppable' Nuclear-Powered Cruise Missile”, The Diplomat, March 2, 2018, https://thediplomat.com/2018/03/russia-revealsunstoppable-nuclear-powered-cruise-missile/, 18/4/2020.

45 "Russia Stages First Ship-Launched 'Tsirkon' Hypersonic Missile Test”, The Moscow Times, 27 February 2020, https:/ / www.themoscowtimes.com/2020/02/27/russiastages-first-ship-launched-tsirkon-hypersonic-missile-test-a69428, 7/3/2020. 
leti brzinom od 9 Maha, ostvarujući domet od 1000 kilometara. ${ }^{46}$ Možemo zaključiti da smo već ušli u eru hipersonične trke u naoružanju jer Rusiju, kao lidera na tom polju, prate SAD i Kina.

Američki analitičar sa Kvinsi instituta u Vašingtonu Stiven Simon (Steven Simon), ispravno je ukazao političko-vojnom vrhu SAD da „nijedan postojeći sistem odbrane, u SAD ili bilo gde drugde na svetu, nije sposoban da obori raketu koja se kreće toliko brzo manevrišući nepredvidivim putanjama" ${ }^{47}$ Pojedini autori, poput urednika američkog časopisa The National Interest, Dejvid Eks (David Axe), osporavaju pouzdanost ruskih i kineskih hipersoničnih raketa, naglašavajući da SAD ne bi trebalo da žure sa operativnim uvođenjem tog oružja u svoj arsenal. ${ }^{48}$ Prema njegovom stavu nije važno ko će prvi napraviti to oružje, već da li će ono biti funkcionalno. ${ }^{49}$

SAD su aktivno radile na razvoju hipersoničnog oružja još početkom XXI veka, kroz konvencionalni program „Prompt Global Strike”. ${ }^{50}$ Međutim, finansiranje je bilo skromno sve dok Rusija i Kina nisu objavile svoje projekte razvoja hipersoničnog oružja. Američko ministarstvo odbrane trenutno razvija hipersonično oružje u okviru ovog programa za mornaricu (US Navy), kao i nekoliko drugih programa u okviru vazduhoplovstva (US Air Force), kopnene vojske (eng. US Army) i DARPA (Defense Advanced Research Projects Agency). ${ }^{51} \mathrm{U}$ nacionalnoj odbrambenoj strategiji (National Defence Strategy) iz 2018. godine, hipersonično oružje je prepoznato kao jedna od ključnih tehnologija koja će „voditi i dobijati” ratove budućnosti. ${ }^{52}$ Za razliku od Rusije i Kine, SAD trenutno ne razvijaju hipersonično oružje sa

\footnotetext{
${ }^{46}$ Ibid.

${ }^{47}$ Citirano u: David Axe, "Be Careful America: Russia's Hypersonic Weapons Are Already Here", The National Interest, 22 January 2020, https:/ / nationalinterest.org/ blog/buzz/be-careful-america-russias-hypersonic-weapons-are-already-here-116311, 22/2/2020.

${ }^{48}$ Ibid.

${ }^{49}$ Ibid.

${ }^{50}$ Kelley M. Sayler, "Hypersonic Weapons: Background and Issues for Congress", Congressional Research Service, Summary, No. R45811, March 17, 2020, p. 1.

51 Ibid., p. 4.

52 "Summary of the 2018 National Defense Strategy of The United States of America", Department of Defense, p. 3, https://dod.defense.gov/Portals/1/Documents/ pubs/2018-National-Defense-Strategy-Summary.pdf., 7/4/2020.
} 
nuklearnim punjenjem, već daleko preciznije oružje sa konvencionalnim bojevim glavama. ${ }^{53}$ Ovakve zvanične konstatacije potrebno je uzeti sa određenom rezervom, jer je dobro poznato da kada se napravi operativna raketa njena modifikacija, u smislu dometa ili punjenja, ne predstavlja veliki tehnološki problem.

Vazduhoplovstvo SAD je testiralo "skramdžet” motor koji sagoreva tečno hidrokarbonsko gorivo. ${ }^{54}$ Ovaj motor je testiran na "X-51" demonstratoru naziva "Waverider" koji je leteo četiri puta između 2010. i 2013. godine..$^{55}$ Trampova administracija je kao odgovor na ruske hipersonične sisteme naoružanja 19. marta 2020. godine testirala HGV na Havajima. ${ }^{56}$ "Ovaj događaj predstavlja prekretnicu u cilju razvoja hipersoničnih ratnih sposobnosti početkom ili sredinom treće decenije XXI veka". ${ }^{57}$ Pentagon je uz snažnu podršku Kongresa ubrzao razvoj hipersoničnog naoružanja kako bi SAD održale korak sa Kinom i Rusijom na ovom polju. ${ }^{58}$ Trampova administracija je zahtevala 3,2 milijarde dolara za 2021. godinu kako bi se ubrzao razvoj ovog oružja, što je uvećanje od 600 miliona u odnosu na 2020. fiskalnu godinu..$^{59}$

Kina je takođe država sa programom razvoja hipersoničnog naoružanja, iako o njemu ima vrlo malo poznatih informacija. Za kineske vojne stratege, hipersonično oružje predstavlja deo strateške slagalice u cilju prevazilaženja „veka poniženja” i zauzimanja novog kursa dominantne sile u indopacifičkom regionu. ${ }^{60} \mathrm{U}$ martu 2018. godine, Kina je obznanila konstrukciju tunela za simulaciju brzina između 10 i 25 Maha. ${ }^{61}$ Članak u South China

${ }^{53}$ Kelley M. Sayler, "Hypersonic Weapons: Background and Issues for Congress", p. 4. ${ }^{54} \mathrm{~J}$. R. Wilson, "The emerging world of hypersonic weapons technology", op. cit., p. 16. ${ }^{55}$ Ibid.

${ }^{56}$ Kingston Reif and Shannon Bugos, "Pentagon Tests Hypersonic Glide Body", Arms Control Today, April 2020, https://www.armscontrol.org/act/2020-04/news/ pentagon-tests-hypersonic-glide-body, 4/5/2020.

${ }^{57}$ Ibid.

${ }^{58}$ Ibid.

${ }^{59}$ Ibid.

${ }^{60}$ John D. Varilek, "U.S. Hypersonic Weapons and China Deterrence Effect”, in: Paige P. Cone (ed.), Assesing The Influence of Hypersonic Weapons on Deterrence, Center for Strategic Deterrence Studies, U.S. Air Force, Future Warfare Series, No. 59, June 2019, p. 49.

${ }^{61}$ J. R. Wilson, "The emerging world of hypersonic weapons technology", op. cit., p. 17. 
Morning Post od 7. januara 2018. godine, tvrdio je kako je Kina navodno u vođstvu kada je reč o razvoju tehnologije hipersoničnog oružja. ${ }^{62} \mathrm{U}$ avgustu 2018, opet prema navodima kineskih medija, Kina je testirala HGV koja je uspešno letela brzinom od 5,5 Maha. ${ }^{63}$ Kineska vojna doktrina se trenutno fokusira na kontrolu morskog koridora, tako da Peking ima interes za razvoj taktičkih hipersoničnih krstarećih raketa $(\mathrm{HCV})$. Ukoliko bi ovladali tehnologijom taktičkih hipersoničnih krstarećih raketa, mogli bi da prinude mornaricu SAD da napuste Južno kinesko more kao zonu uticaja, što je od prvorazrednog strateškog značaja za Kinu.

SAD svoj interes u razvoju hipersoničnog oružja vide na drugi način. Većina ratova koje su vodile SAD dešavali su se na istočnoj hemisferi, što je oduzimalo mnogo vremena, resursa i energije za dopremanje jedinica i njihovo kasnije snabdevanje. Hipersonično oružje bi u tom kontekstu umanjilo broj potrebnih jedinica za delovanje u područjima koja su daleko od matične teritorije SAD. U odnosu prema Rusiji, kao državi koja je najviše odmakla u razvoju novog oružja, SAD moraju da održe korak i razviju hipersonično oružje dugog dometa kojim bi mogli da gađaju udaljene ciljeve na istočnoj hemisferi. $U$ februaru 2020. godine američka DARPA objavila je rad na protiv-hipersoničnoj odbrani pod nazivom "Glide Breaker" ${ }^{64}$ Ovaj sistem bi trebalo da obara HGV poput ruskog "Avangarda”, a njegovo testiranje se očekuje do kraja 2020. godine ${ }^{65}$ Koliko je ovo težak poduhvat govore i američki stručnjaci poredeći antibalističke sisteme sa „gađanjem metka metkom u punoj brzini", dodajući da je u slučaju hipersoničnih raketa taj metak potpuno nepredvidive putanje kretanja. ${ }^{66}$ Međutim, neki eksperti, poput Džejmsa Aktona (James Acton), smatraju da je moguće napraviti odbranu od HGV na bazi odbrambenih sistema kao što je američki THAAD

${ }^{62}$ Citirano u: George Friedman, "Where Hypersonic Weapons Fit in the Future of War", op. cit.

${ }^{63}$ Steven Stashwick, "China Tests New 'Waverider' Hypersonic Vehicle”, The Diplomat, August 9 2018, https://thediplomat.com/2018/08/china-tests-new-waveriderhypersonic-vehicle/,15/4/2020.

${ }^{64}$ Michael Peck, "Worried About Russian and Chinese Hypersonic Weapons? DARPA Isn't", The National Interest, 13 Feburary 2020, https://nationalinterest.org/ blog/buzz/worried-about-russian-and-chinese-hypersonic-weapons-darpa-isnt$123261,19 / 4 / 2020$.

${ }^{65}$ Ibid.

66 Ibid. 
(eng. Terminal High Altitute Area Defence) koji čistom kinetičkom energijom obara balističke rakete $u$ završnoj fazi leta ${ }^{67}$ Problem sa takvim sistemom leži u činjenici da on pokriva vrlo mali deo teritorije i da bi prekrivanje čitave američke teritorije takvim sistemima koštalo enormne svote novca ${ }^{68}$

Bez obzira na verovatno fingiranje određenih informacija $u$ cilju demonstracije sopstvene moći, evidentno je da su Rusija, SAD i Kina duboko zagazile na put razvoja hipersoničnog oružja. Na tom putu, najvišeje odmakla Rusija koja je, za sada, jedina država na svetu sa operativnim hipersoničnim arsenalom. Rusija svoje hipersonično oružje nije razvila preko noći, kako na prvi pogled deluje čitajući publicističke objave. Iza operativnog uvođenja sistema "Avangard" stoji više od 30 godina rada na razvoju, ne računajući prethodne sovjetske programe hipersoničnog oružja koji su postojali od šezdesetih do osamdesetih godina XX veka ${ }^{69} \mathrm{Uz}$ periode stagnacije, Rusija je uložila ozbiljan novac i ljudski potencijal u razvoj hipersoničnog oružja, nakon što su SAD napustile "ABM" sporazum 2002. godine. ${ }^{70}$ Strah od američkog antiraketnog štita naterao je Rusiju da ubrza i pojača rad na razvoju novog ofanzivnog naoružanja, kao vid polise osiguranja za očuvanje strateškog balansa. Da ironija bude veća, Rusija je uspela da razvije oružje koje probija sistem odbrane a koji SAD još uvek nisu razvile u potpunosti. ${ }^{71}$

Duh je tek pušten iz boce i trka u razvoju hipersoničnog oružja može podsetiti na hladnoratovsku trku u razvoju nuklearnih arsenala. Nekadašnji ekskluzivitet u nuklearnom klubu može biti zamenjen novim, još elitnijim "hipersoničnim klubom”. Međutim, za razliku od tabua nuklearnog oružja uspostavljenog neproliferacionim režimom, hipersonično oružje ne trpi takve negativne efekte međunarodne stigmatizacije. ${ }^{72}$ To znači da je za

${ }^{67}$ Ibid.

${ }^{68}$ Ibid.

${ }^{69}$ Michael Kofman, "Beyond the Hype of Russia's Hypersonic Weapons", The Moscow Times, 16 January 2020, https://www.themoscowtimes.com/2020/01/15/russiashypersonic-weapons-a68907, 2/4/2020.

${ }^{70}$ Ibid.

${ }^{71}$ Ibid.

${ }^{72}$ Neproliferacioni režim je uspostavljen stupanjem na snagu Sporazuma o neširenju nuklearnog naoružanja 1970. godine. To je osnovni dokument koji sprečava "rađanje” novih nuklearnih sila. Videti: "Treaty on the Non-Proliferation of Nuclear Weapons", United Nations, 1968, https://www.un.org/disarmament/wmd/nuclear/npt/, $19 / 4 / 2020$. 
razliku od donekle zauzdane "nuklearne trke”, hipersonična trka u potpunosti dozvoljena, pa bi Japan, Švedska ili Južna Koreja mogli da razviju hipersoničnu raketu, za razliku od nuklearnih bombi. Režim kontrole raketne tehnologije (Missile Technology Control Regime - MTCR) isključivo je neformalnog karaktera koji okuplja 35 nacija. ${ }^{73}$ MTCR zabranjuje širenje pojedinih komponenti u raketnoj tehnologiji, ali odluke koje donosi nisu obavezujućeg karaktera. ${ }^{74}$ Osim toga, MTCR zabranjuje samo tehnologiju nuklearnog, hemijskog ili biološkog punjenja, što ne mora biti nužan slučaj kod hipersoničnog oružja koje može da ima konvencionalno punjenje. $^{75}$ Međutim, ograničavajući faktor širenja hipersoničnog oružja na veliki broj država u praksi predstavlja njihova sofisticiranost. Za njihov razvoj potrebni su ogromni naučni, materijalni i tehnološki kapaciteti, koje danas poseduju sasvim sigurno SAD, Kina i Rusija, uz potencijalno nove igrače kao što su Francuska i Indija. ${ }^{76}$

Vrlo mali broj država raspolaže uopšte tehnologijom interkontinentalnih balističkih raketa, što je u tehnološkom smislu korak ispod koncepta hipersoničnog naoružanja. Osim toga, prvorazredni defanzivni kapaciteti koje nudi hipersonično oružje zahteva veću destruktivnu moć, tj. nuklearno punjenje. Danas je na svetu samo devet nuklearnih sila (SAD, Rusija, Ujedinjeno Kraljevstvo, Francuska, Kina, Indija, Pakistan, Izrael i Severna Koreja), koje bi u kombinaciji sa hipersoničnom silom mogle odvratiti neprijateljski napad. Kada govorimo o novom hipersoničnom naoružanju, situaciju najbolje objašnjava poznata rečenica Vilijama Gibsona (William Gibson): „Budućnost je već stigla, samo još uvek nije ravnomerno raspoređena." 77

\footnotetext{
73 "MTCR partners", Missile Technology Control Regime, Internet, https:/ / mtcr.info/ partners/, 4/5/2020.

74 "MTCR Guidelines and the equipment, software and technology annex", Missile Technology Control Regime, Internet, https://mtcr.info/mtcr-guidelines/, 4/5/2020. ${ }^{75}$ Ibid.

${ }^{76} \mathrm{~J}$. R. Wilson, "The emerging world of hypersonic weapons technology", op. cit., p. 23.

${ }^{77}$ Citirano u: Michael Kofman, "Beyond the Hype of Russia's Hypersonic Weapons", op. cit.
} 


\section{Zaključna razmatranja}

Tema razvoja hipersoničnog naoružanja tek je otvorena u akademskoj zajednici, i s obzirom na to da se radi o potpuno novom naoružanju za sada postoje skromni podaci upitne verodostojnosti. Donošenje konačnih zaključaka u tom polju veoma je težak zadatak. Ono što sa sigurnošću možemo zaključiti jeste da je Rusija trenutno lider na ovom polju, i trenutno jedina država koja je u svoje operativne arsenale uvela novo hipersonično oružje. Rusija je razvila novo naoružanje kako bi povratila stratešku ravnotežu i predupredila potencijalni razvoj protivraketnog štita SAD, koji bi mogao neutralisati napad "klasičnim” balističkim i krstarećim raketama. Kina i SAD prate korak sprovodeći sopstvene programe razvoja hipersoničnog oružja. Primarni interes Kine jeste jačanje ofanzivnih kapaciteta na moru kako bi stekla dominantan položaj u indo-pacifičkom regionu i istisnula američki uticaj iz tog regiona. Na drugoj strani, SAD za sada razvijaju isključivo hipersonično oružje sa konvencionalnim punjenjem, jer im se osnovni ciljevi ogledaju u preciznosti i mobilnosti konvencionalnih snaga. SAD imaju osiguran dominantan strateški položaj i bez hipersoničnog oružja, ali su najviše "osakaćene" ruskim i kineskim ulaganjem u oružje koje bez problema probija svaki protivraketni štit. SAD su uložile milijarde dolara u sistem protivraketne odbrane koji je obesmišljen postojanjem neuhvatljivog hipersoničnog oružja. Svetu predstoji jedna nova trka u naoružanju koja će u budućnosti uključiti ne samo razvoj hipersoničnog oružja, već i sisteme odbrane od njega, na čemu već rade SAD. U novoj trci, za razliku od ere Hladnog rata, imaćemo najmanje tri učesnika, ali će se pored Rusije, Kine i SAD u trku uključiti druge nuklearne sile poput Francuske, Ujedinjenog Kraljevstva ili Indije.

Pored činjenice da je ogromni tehnološki napredak, hipersonično oružje ne predstavlja revoluciju u vojnim poslovima, jer osim što pojačava ofanzivne mogućnosti prema sistemima odbrane, suštinski ne menja odnos snaga između država koje takve sisteme ne poseduju. Na polju strategije odvraćanja, hipersonično oružje koje nosi nuklearne bojeve glave dodatno kompresuje vreme neophodno za izdavanje naredbe za kontraudar. Ono, takođe, uvećava rizik od preventivnog udara koji bi efikasno neutralisao političko-vojni vrh napadnute države. Sve ovo može rezultirati promenama u operativnoj komandi i voditi ka većoj decentralizaciji kako bi se osigurao kapacitet za drugi udar. Hipersonično oružje je sadašnjost međunarodnih odnosa i nova varijabla koja će biti predmet budućih strateških kalkulacija. 
Sigurno je samo to - da će mnoge države težiti članstvu u „hipersoničnom klubu", a on će biti rezervisan isključivo za najmoćnije.

\section{Bibliografija}

Baudrillard, Jean, The Gulf War did not take place, Bloomington: Indiana University Press, 1995.

Croddy, Eric A. and Wirtz, James J. (eds.), Weapons of mass destruction: an encyclopedia od worldwide policy, technology and history, ABC Clio, Santa Barbara, California, 2005.

Ford, Daniel, A Vision So Noble - John Boyd, the OODA Loop, and Americas War on Terror, CreateSpace Independent Publishing Platform, 2010.

Futter Andrew, Ballistic Missile Defence and US National Security Policy: Normalization and acceptance after the Cold War, Routledge, New York, 2013.

Hodge, Nathan, "Putin claims Russia is world leader on hypersonic weapons", CNN, December 25, 2019.

Kaldor, Meri, Novi i stari ratovi - organizovano nasilje u globalizovanoj eri, Beogradski krug, Beograd.

Kegli, Čarls i Judžin, Vitkof, Svetska politika, Centar za studije Jugoistočne Evrope, FPN i DA Ministarstva spoljnih poslova SCG, Beograd, 2006.

Kurmon, Bartelemi i Darko Ribnikar, Asimetrični ratovi, NIC Vojska, Beograd, 2003.

Петровић, Драган и Богдан, Стојановић, Равнотежка нуклеарне моћи САД и Русије (СССР), Пешић и синови, Центар за развој међународне сарадње, Београд, 2012.

Sayler, Kelley M., "Hypersonic Weapons: Background and Issues for Congress", Congressional Research Service, Summary, No. R45811, March 17, 2020.

Speier, Richard H., George, Nacouzi, Carrie, A. Lee and Richard, M. Moore, "Hypersonic Missile Nonproliferation: Hindering the Spread of a New Class of Weapons", Report, RAND Corporation, 2017, pp. 2-5.

Стојановић, Богдан, „Преиспитивање теорије и праксе нуклеарног одвраћања" , Национални интерес, Година X, Vol. 17, Број 2, 2013, стр. 141-172. 
Tarasova, Darya, Zahra, Ullah and Jack, Guy, "Russia's Vladimir Putin oversees hypersonic missile test near Crimea", CNN, January 9, 2020.

Varilek, John D., "U.S. Hypersonic Weapons and China Deterrence Effect”, in: Paige P. Cone (ed.), Assesing The Influence of Hypersonic Weapons on Deterrence, Center for Strategic Deterrence Studies, U.S. Air Force, Future Warfare Series, No. 59, June 2019, pp. 35-55.

Wilson, J. R., "The emerging world of hypersonic weapons technology", Special report, Military \& Aerospace Electronics, 2019.

\section{Internet izvori}

"Avangard: Russia deploys hypersonic nuclear-capable missiles", Al Jazeera, 27 December 2019, https://www.aljazeera.com/news/2019/12/ avangard-russia-commissions-intercontinental-hypersonic-weapon191227142922561.html, 13/3/2020.

Axe, David, "Be Careful America: Russia's Hypersonic Weapons Are Already Here", The National Interest, 22 January 2020, https:/ / national interest.org/blog/buzz/be-careful-america-russias-hypersonicweapons-are-already-here-116311, 22/2/2020.

Boese, Wade, "U.S. Withdrawal From ABM Treaty; Global Response Muted", Arms Control Today, July/August 2002, https://www.arms control.org/act/2002-07/news/us-withdraws-abm-treaty-globalresponse-muted, 15/3/2020.

Cummings, Alan, "Hypersonic weapons: tactical uses and strategic goals", War on the rocks, November 12, 2019, https://warontherocks.com/ 2019/11/hypersonic-weapons-tactical-uses-and-strategic-goals/, 10/1/2020.

Friedman, George, "Where Hypersonic Weapons Fit in the Future of War", Geopolitical Futures, January 10, 2018, https:/ / geopoliticalfutures.com/ hypersonic-weapons-fit-future-war/, 12/3/2020.

Gady, Franz-Stefan, „Report: Russia Has Developed Prototype of Air-toGround Hypersonic Missile for Su-57", The Diplomat, 25 February 2020, https://thediplomat.com/2020/02/ report-russia-has-developedprototype-of-air-to-ground-hypersonic-missile-for-su-57/, 20/3/2020.

Gady, Franz-Stefan, “Russia Reveals 'Unstoppable' Nuclear-Powered Cruise Missile", The Diplomat, March 2, 2018, https://thediplomat. 
com/2018/03/russia-reveals-unstoppable-nuclear-powered-cruisemissile/, 18/4/2020.

Kofman, Michael, "Beyond the Hype of Russia's Hypersonic Weapons", The Moscow Times, 16 January 2020, https:/ / www.themoscow times. com/2020/01/15/russias-hypersonic-weapons-a68907, 2/4/2020.

"Mach number", National Aeronautics and Space Administration, Glenn Research Center, https://www.grc.nasa.gov/www/k-12/airplane/ mach.html, 12/1/2020.

"MTCR Guidelines and the equipment, software and technology annex", Missile Technology Control Regime, https://mtcr.info/mtcr-guidelines/, 4/5/2020.

"MTCR partners", Missile Technology Control Regime, https://mtcr.info/ partners/ , 4/5/2020.

Peck, Michael, "Worried About Russian and Chinese Hypersonic Weapons? DARPA Isn't", The National Interest, 13 Feburary 2020, https:/ / national interest.org/blog/buzz/worried-about-russian-and-chinese-hypersonic -weapons-darpa-isnt-123261, 19/4/2020.

"Putin unveils new nuclear weapons", 1.3.2018., CBC News: The National, Youtube video, https://www.youtube.com/watch?v=X7bUHc4jAI0, 2/2/2020.

Reif, Kingston and Shannon, Bugos, "Pentagon Tests Hypersonic Glide Body", Arms Control Today, April 2020, https:/ / www.armscontrol.org/ act/2020-04/news/pentagon-tests-hypersonic-glide-body, 4/5/2020.

"Russia Stages First Ship-Launched 'Tsirkon' Hypersonic Missile Test", The Moscow Times, 27 February 2020, https:/ / www.themoscowtimes.com/ 2020/02/27/ russia-stages-first-ship-launched-tsirkon-hypersonicmissile-test-a69428, 7/3/2020.

"Russia's new hypersonic weapons help maintain global strategic balance - Putin", Putin's interview, TASS, 2 March 2020, https://tass.com/ politics/1125437, 15/3/2020.

Stashwick, Steven, "China Tests New 'Waverider' Hypersonic Vehicle", The Diplomat, August 9 2018, https://thediplomat.com/2018/08/chinatests-new-waverider-hypersonic-vehicle/, 15/4/2020.

"Summary of the 2018 National Defense Strategy of The United States of America", Department of Defense, https://dod.defense.gov/Portals/ 
1/Documents/pubs/2018-National-Defense-Strategy-Summary.pdf, $7 / 4 / 2020$.

"Treaty on the Non-Proliferation of Nuclear Weapons", United Nations, 1968, https://www.un.org/disarmament/wmd/nuclear/npt/,19/4/ 2020.

\section{Bogdan STOJANOVIĆ}

\section{HYPERSONIC WEAPONS: STRATEGIC BALANCE DISORDER OR A NEW ARMS RACE?}

Abstract: Testing and introduction of hypersonic weapons into operational use have made a megalomaniacal investment in missile defense projects meaningless. The attempt to avoid mutually assured destruction through the development of an effective missile shield by the United States reflected the intention to disrupt the strategic balance by preventing possible retaliation and preventing the second strike capability of an enemy. The Cold War concepts of mutually assured destruction (MAD) and deterrence strategy would be called into question. Hypersonic weapons, although the last word in science and technology, do not represent a revolution in military affairs. It is not capable of disturbing the strategic military balance between the former Cold War opponents, but it is a kind of guarantee of its preservation. By introducing hypersonic weapons into operational use, Russia did not disrupt the strategic balance in its favor but prevented the United States from doing so by developing a missile defense system. A new arms race for acquiring weapons has begun, moving five or more times faster than the speed of sound. The outlines of the new arms race are similar to the conquest of space, without compromising strategic balance, but extremely significant in the context of prestige. Membership in the "hypersonic club" will be the privilege of the most powerful countries, like the former exclusivity offered by membership in the "nuclear club".

Keywords: hypersonic weapons, strategic balance, deterrence strategy, mutually assured destruction, anti-missile system, revolution in military affairs, the USA, Russia, China. 